\title{
The Activities of the State Labour Inspectorate in the Kurgan Region
}

\author{
Roznina N.V.* \\ Department of Accounting and Finance \\ Kurgan State Agricultural Academy named after T.S. Maltsev \\ Kurgan, Russia \\ e-mail: Rozninanina@mail.ru
}

Sokolova E.S.

Department of Power supply and radio telemechanics Tyumen Higher Military Engineering Command School Tyumen, Russia

e-mail: sok-evgenia@yandex.ru

\author{
Karpova M.V. \\ Department of Marketing and Agricultural Business \\ Organisation \\ Kurgan State Agricultural Academy named after T.S. Maltsev \\ Kurgan, Russia \\ e-mail: mdusheva@rambler.ru
}

\author{
Schulgina A.V. \\ Department of Finance and Economic security, Institute of Economics and Law \\ Kurgan State University \\ Kurgan, Russia \\ e-mail: schulgina@yandex.ru
}

\begin{abstract}
The work describes the legislative acts in the sphere of labour which form the basis for the activities of the State Labour Inspectorate (SLI) in the Kurgan region. The article also describes the performance of SLI in the region between 2015 and 2019. We consider the number of inspections carried out by the SLI in all economic entities, the sums of administrative fines imposed and collected for abusing employment and labour laws, the change in the numbers of investigated work accidents. We also studied the types of work accidents that are common in the Kurgan region and carried out the analysis that showed the causes leading to work accidents of different severity.
\end{abstract}

Keywords - work safety, State Labour Inspectorate, work accidents.

\section{INTRODUCTION}

The State Labour Inspectorate (SLI) base its labour law enforcement activities on the provisions of the International Labour Organization Convention established in 1947. The convention was ratified by the Federal Law No. 58-FZ of April 14, 1998, the Constitution of the Russian Federation, the Code of Administrative Offences of the Russian Federation, the Federal Law No. 294-FZ of December 26, 2008 "On the rights of legal entities and sole proprietors during the implementation of state and municipal control", the Provisions of the State Labour Inspectorate in the Kurgan region.

The SLI of the Kurgan region is formed by the Federal Labour and Employment Service order no. 174 of March 31, 2017 "On the approval of regulations about the local Federal Labour and Employment Service agency — the State Labour
Inspectorate in the Kurgan region." The act states that the inspectorate is the local Federal Labour and Employment Service agency that performs state supervision of the implementation of labour law and other regulations, containing the norms of labour law in the Kurgan region. The act also describes the authority of the inspectorate in this sphere.

\section{RESULTS AND DISCUSSION}

Labour safety is a system that ensures the preservation of workers' health and lives at the workplace. It includes legal, social, economic, organisational, technical, medical, preventive, sanitary, hygienic, rehabilitative, and other activities $[8,12]$. The SLI in the Kurgan region regularly performs state supervision of the implementation of labour law and other regulations, containing the norms of labour law including those related to work safety $[5,13]$.

The performance of the SLI in the Kurgan region between 2015 and 2019 is represented in table 1.

The number of inspections carried out by the SLI in the Kurgan region decreased between 2015 and 2019 by 206 cases through the reduction of inspections in business entities by 168 cases and sole proprietors by 38 cases. This is partially due to a decrease in the total number of economic entities in the Kurgan region between 2015 and 2019. This number declines by $9.01 \%$ or 3,168 entities because of the reduction in the number of sole proprietors by $2.47 \%$ or 443 entities and business entities by 15.83 or $27.25 \%$. 
In 2019 the SLI in the Kurgan region performed on-site and documentary inspections both planned and exceptional based on requests by workers, the information from state authorities, and notifications of work accidents in different economic entities of the region. The total number of these inspections reached 895 cases which is 206 cases less than in 2015. This is due to the reduction of planned inspections by 122 cases and inspections upon worker's request by 173 cases.

TABLE I. THE PERFORMANCE OF THE SLI IN THE KURGAN REGION

\begin{tabular}{|l|l|l|l|l|l|}
\hline \multicolumn{1}{|c|}{ Indicator } & \multicolumn{1}{|c|}{$\mathbf{2 0 1 5}$} & $\mathbf{2 0 1 6}$ & \multicolumn{1}{|c|}{$\mathbf{2 0 1 7}$} & $\mathbf{2 0 1 8}$ & \multicolumn{1}{|c|}{$\mathbf{2 0 1 9}$} \\
\hline $\begin{array}{l}\text { The number of inspections in different } \\
\text { legal entities, total }\end{array}$ & 1,101 & 964 & 1,133 & 858 & 895 \\
\hline including sole proprietors & 128 & 98 & 172 & 118 & 90 \\
\hline business entities & 973 & 866 & 961 & 740 & 805 \\
\hline Grounds for inspections, total & 1,101 & 964 & 1,133 & 858 & 895 \\
\hline including planned inspections & 150 & 89 & 92 & 72 & 28 \\
\hline $\begin{array}{l}\text { inspections for monitoring the } \\
\text { execution of precepts that were issued } \\
\text { during previous checks }\end{array}$ & 7 & 4 & 42 & 40 & 86 \\
\hline upon requests by citizens & 921 & 851 & 934 & 722 & 748 \\
\hline other grounds & 23 & 20 & 65 & 24 & 33 \\
\hline $\begin{array}{l}\text { The total number of decisions on } \\
\text { imposing fines issued by the } \\
\text { employees of the SLI }\end{array}$ & 1,023 & 998 & 877 & 612 & 639 \\
\hline including those issued to officials & 571 & 590 & 503 & 267 & 266 \\
\hline issued to sole proprietors & 136 & 117 & 98 & 36 & 50 \\
\hline issued to business entities & 316 & 291 & 276 & 309 & 323 \\
\hline $\begin{array}{l}\text { The sum of administrative fines } \\
\text { imposed, thousand roubles in total }\end{array}$ & $16,156.6$ & $18,471.5$ & 18,009 & 19,212 & 20,579 \\
\hline including those imposed on officials & $2,680.50$ & $2,723.50$ & $3,510.50$ & $2,273.00$ & $2,031.50$ \\
\hline imposed on sole proprietors & 540.50 & 614.50 & 463.5 & 180 & 203.00 \\
\hline imposed on business entities & $12,960.9$ & $15,133.3$ & $14,035.0$ & 16,759 & 18,345 \\
\hline $\begin{array}{l}\text { The sum of administrative fines paid, } \\
\text { thousand roubles in total }\end{array}$ & $12,960.9$ & $15,372.7$ & $15,787.3$ & $15,482.4$ & $14,918.2$ \\
\hline
\end{tabular}

The total number of decisions on imposing fines issued by the employees of the SLI in 2019 reached 639 cases which is 384 cases less than in 2015 . This is due to the reduction in the number of decisions issued to officials by 384 cases and sole proprietors by 86 cases. The total number of decisions on imposing fines issued by the employees of the SLI to business entities in the described period increased by 7 cases and reached 323 cases in 2019.

Despite the decrease in the total number of decisions on imposing fines between 2015 and 2019, the total sum of fines increased by 4422.37 thousand roubles and reached 20,579 thousand roubles in 2019. This is due to the increase in the number of fines imposed on business entities by 5,384.02 thousand roubles.

The sum of paid fines increased between 2015 and 2017 but then started to decline [10]. Between 2015 and 2019 the sum of paid administrative fines increased by $1,957.31$ thousand roubles and reached 14,918.29 thousand roubles in 2019.

The percentage of paid fines for the total amount of fines in 2019 was $72.49 \%$ which is $7.73 \%$ less than in 2015 .

According to the article 356 of the Labour Code of the Russian Federation, the SLI of the Kurgan region performs activities aimed at investigating work accidents in different economic entities of the region, determining the causes of work traumas, and developing measures for their prevention $[4,6]$.

For the described period, the number of work accidents in economic entities of the Kurgan region decreased both in terms of registered and investigated accidents.
The total number of registered and investigated cases in 2019 reached 20 cases which is 17 cases or $45.59 \%$ lower than in 2015 (Table 2). We should note the decrease in the number of severe and fatal accidents by 9 and 8 cases correspondingly.

TABLE II. THE NUMBER OF INVESTIGATED WORK ACCIDENTS IN THE KURGAN REGION

\begin{tabular}{|l|l|l|l|l|l|}
\hline \multicolumn{1}{|c|}{ Indicator } & $\mathbf{2 0 1 5}$ & $\mathbf{2 0 1 6}$ & $\mathbf{2 0 1 7}$ & $\mathbf{2 0 1 8}$ & \multicolumn{1}{|c|}{$\mathbf{2 0 1 9}$} \\
\hline Total number of investigated accidents & 37 & 31 & 30 & 16 & 20 \\
\hline including group accidents & 2 & - & 2 & - & 2 \\
\hline severe accidents & 24 & 23 & 24 & 13 & 15 \\
\hline fatal accidents & 11 & 8 & 4 & 3 & 3 \\
\hline $\begin{array}{l}\text { The frequency coefficient of work } \\
\text { accidents according to Kurganstat (Cf) }\end{array}$ & 1.7 & 1.4 & 1.4 & 1.1 & $\begin{array}{l}\text { Data } \\
\text { available in } \\
\text { May 2020 }\end{array}$ \\
\hline
\end{tabular}

In comparison with the 2015-2018 period, 2019 showed a significant decrease in work accidents by $25.37 \%$ [11] of the total number of accidents with different categories including severe (by $24,24 \%$ ) and fatal $(48.28 \%)$. The number of group accidents in 2019 increased by $66.67 \%$ in comparison to the period between 2015 and 2018 .

The biggest share among all investigated work cases in the Kurgan region between 2015 and 2019 still belongs to severe cases. In the described period they account for $62.55 \%$ (the highest value was in 2018 reaching $81.25 \%$ ). The average number of investigated fatal cases between 2015 and 2019 was $17.11 \%$ (the highest value was in 2015 reaching $29.73 \%$ ) while for group cases it was $3.68 \%$ (the highest value was in 2018 reaching $10.0 \%$ ).

In 2019 the main causes of work accidents were:

- the inadequate organisation of work - 6 severe accidents, 1 fatal accident, 1 group accident (Table 3). This was the cause of $40 \%$ of accidents that happened in 2019 .

- other causes (wrongdoings of other persons, inadequate control over work safety) - 1 fatal accident, 4 severe accidents. This was the cause of $25 \%$ of accidents in 2019.

In 2019 the number of accidents due to an inadequate organisation of work decreased from 10 to 8 accidents or by $20 \%$. At the same time, there is an increase in the number of accidents due to "other cases, determined during the investigation" from 1 to 5 cases or by $80 \%$.

The biggest number of work accidents in the Kurgan region happened due to inadequate organisation of work. In 2015 this was the cause of 21 accidents which is 13 accidents higher than in 2019. Other causes determined during investigation accounted for 10 accidents in 2015 and 5 accidents in 2019 . We should note that such a cause as a violation of discipline appeared only in 2018.

The biggest share of all work accidents that happened in 2019 belongs to accidents due to an inadequate organisation of work - $40 \%$. The number of accidents that happened due to other reasons determined during the investigation is also high and accounts for $25 \%$ (Fig. 1). 


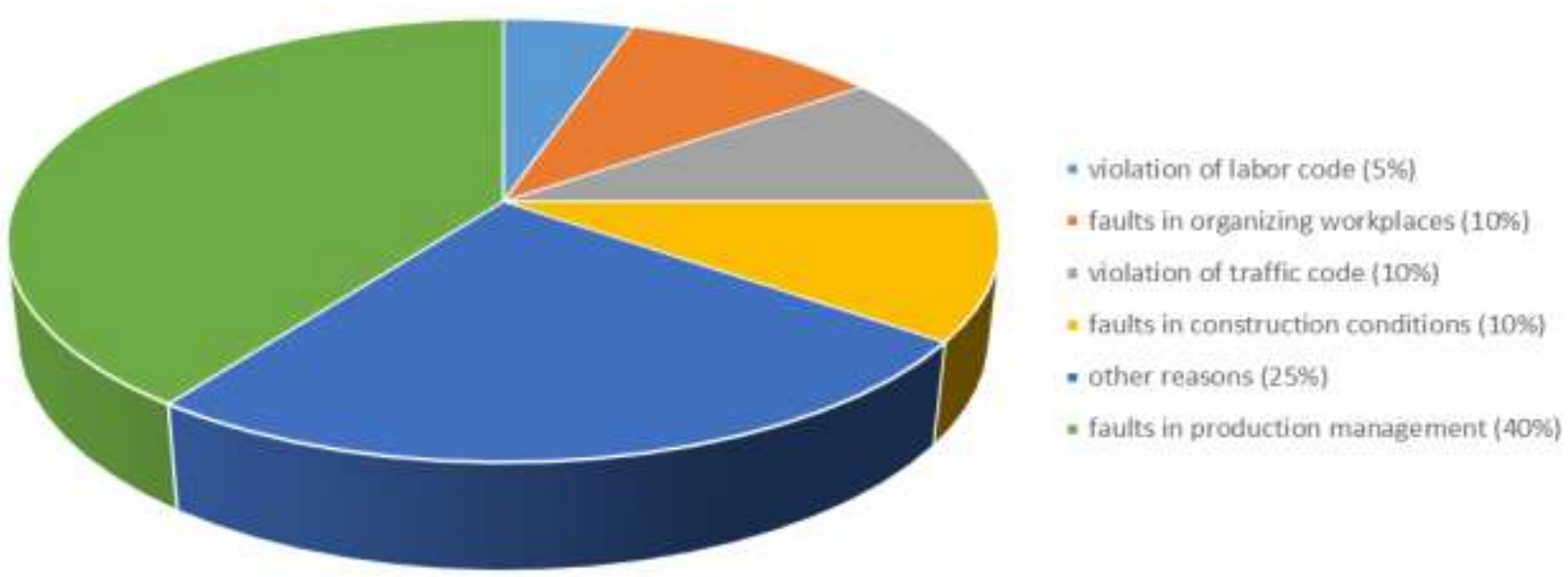

Fig. 1. The structure of causes for work accidents in economic entities of the Kurgan region for 2019, \%

TABLE III. CHANGES IN THE CAUSES OF WORK ACCIDENTS BETWEEN 2018 AND 2019

\begin{tabular}{|l|l|l|l|l|l|l|}
\hline \multirow{2}{*}{ Cause } & \multicolumn{3}{|c|}{$\mathbf{2 0 1 8}$} & \multicolumn{3}{c|}{$\mathbf{2 0 1 9}$} \\
\cline { 2 - 7 } & $\begin{array}{c}\text { group } \\
\text { accidents }\end{array}$ & $\begin{array}{c}\text { severe } \\
\text { accidents }\end{array}$ & $\begin{array}{c}\text { fatal } \\
\text { accidents }\end{array}$ & $\begin{array}{c}\text { group } \\
\text { accidents }\end{array}$ & $\begin{array}{c}\text { severe } \\
\text { accidents }\end{array}$ & $\begin{array}{c}\text { fatal } \\
\text { accidents }\end{array}$ \\
\hline $\begin{array}{l}\text { Total in the } \\
\text { Kurgan region } \\
\text { including: }\end{array}$ & - & 13 & 3 & 2 & 15 & 3 \\
\hline $\begin{array}{l}\text { Inadequate } \\
\text { technical } \\
\text { conditions of } \\
\text { buildings, } \\
\text { facilities, or } \\
\text { territory }\end{array}$ & - & 1 & - & - & 2 & - \\
\hline $\begin{array}{l}\text { Traffic } \\
\text { violation }\end{array}$ & - & 1 & - & 1 & 1 & - \\
\hline $\begin{array}{l}\text { Inadequate } \\
\text { organisation of } \\
\text { work }\end{array}$ & - & 9 & 1 & 1 & 6 & 1 \\
\hline $\begin{array}{l}\text { Inadequate } \\
\text { upkeep and } \\
\text { organisation of } \\
\text { workplaces }\end{array}$ & - & - & - & - & 1 & 1 \\
\hline $\begin{array}{l}\text { Violation of } \\
\text { workplace } \\
\text { discipline }\end{array}$ & - & 1 & 2 & - & 1 & - \\
\hline $\begin{array}{l}\text { including being } \\
\text { drunk }\end{array}$ & - & - & 1 & - & - & - \\
\hline $\begin{array}{l}\text { Other causes } \\
\text { determined } \\
\text { during } \\
\text { investigation }\end{array}$ & - & 1 & - & - & 4 & 1 \\
\hline
\end{tabular}

The types of work traumas investigated by the SLI in the Kurgan region in 2019 are the following (Table 5):

- fall from height -2 fatal and 5 severe accidents accounting for $35 \%$ of the total number of accidents in economic entities of the Kurgan region;

- the action of moving, rotating, flying parts, objects, or machinery, and entrapment between moving and immobile machines and parts -5 severe accidents

accounting for $17.5 \%$ of the total number of accidents in economic entities of the Kurgan region;

- wrongdoings of other persons -2 severe and 1 fatal accidents accounting for $15 \%$ of the total number of work accidents;

- traffic accidents - 1 group accident and 1 severe accident accounting for $10 \%$ of the total number of work accidents;

- fall or collapse of objects, materials, land, etc. 1 severe accident accounting for $5 \%$ of the total number of work accidents;

- electric shock - 1 group accident accounting for $5 \%$ of the total number of work accidents;

- harm due to the contact with plants, animals, insects, or reptiles -1 severe accident accounting for $5 \%$ of the total number of work accidents;

TABLE IV. THE CAUSES OF WORK ACCIDENTS IN THE KURGAN REGION

\begin{tabular}{|l|l|l|l|l|l|}
\hline \multicolumn{1}{|c|}{ Cause } & $\mathbf{2 0 1 5}$ & $\mathbf{2 0 1 6}$ & $\mathbf{2 0 1 7}$ & $\mathbf{2 0 1 8}$ & $\mathbf{2 0 1 9}$ \\
\hline $\begin{array}{l}\text { The total number of accidents in the Kurgan } \\
\text { region including: }\end{array}$ & 37 & 31 & 30 & 16 & 20 \\
\hline $\begin{array}{l}\text { Use of defective machinery, mechanisms, } \\
\text { and equipment }\end{array}$ & 2 & 1 & 1 & - & - \\
\hline Traffic violation & 2 & 1 & 5 & 1 & 2 \\
\hline Inadequate organisation of work & 21 & 17 & 10 & 10 & 8 \\
\hline $\begin{array}{l}\text { Inadequate technical conditions of buildings, } \\
\text { facilities, or territory }\end{array}$ & 0 & 1 & & 1 & 2 \\
\hline $\begin{array}{l}\text { Inadequate upkeep and organisation of } \\
\text { workplaces }\end{array}$ & - & 2 & 1 & - & 2 \\
\hline Violation of workplace discipline & - & - & - & 3 & 1 \\
\hline $\begin{array}{l}\text { Giving a worker the task that doesn't match } \\
\text { his or her skills }\end{array}$ & 1 & 0 & 1 & - & - \\
\hline Negligence of personal protective equipment & 0 & 2 & 1 & - & - \\
\hline Negligence of technological process & 1 & - & 1 & - & - \\
\hline Design flaws & - & - & 1 & - & - \\
\hline Other causes determined during investigation & 10 & 7 & 9 & 1 & 5 \\
\hline
\end{tabular}


TABLE V. TYPES OF ACCIDENTS IN ECONOMIC ENTITIES OF THE KURGAN REGION

\begin{tabular}{|c|c|c|c|c|c|c|}
\hline \multirow[b]{2}{*}{ Type of accident } & \multicolumn{3}{|c|}{2018} & \multicolumn{3}{|c|}{2019} \\
\hline & 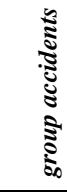 & 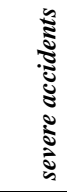 & 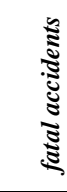 & 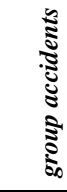 & 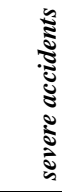 & 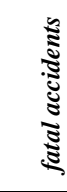 \\
\hline $\begin{array}{l}\text { The total number of } \\
\text { accidents in the } \\
\text { Kurgan region }\end{array}$ & 0 & 13 & 3 & 2 & 15 & 3 \\
\hline Traffic accidents, total & & 1 & & 1 & 1 & \\
\hline $\begin{array}{l}\text { including ground } \\
\text { transport }\end{array}$ & & 1 & & 1 & 1 & \\
\hline Falling from height & & 1 & & & 5 & 2 \\
\hline $\begin{array}{l}\text { Fall or collapse of } \\
\text { objects, materials, } \\
\text { land, etc. }\end{array}$ & & 2 & & & 1 & \\
\hline $\begin{array}{l}\text { The action of moving, } \\
\text { rotating, flying parts, } \\
\text { objects, or machinery, } \\
\text { etc. }\end{array}$ & & 7 & 3 & & 5 & \\
\hline $\begin{array}{l}\text { Fall of extraneous } \\
\text { body }\end{array}$ & & 1 & & & & \\
\hline Electric shock & & & & 1 & & \\
\hline $\begin{array}{l}\text { Impact of harmful } \\
\text { substances }\end{array}$ & & & & & & \\
\hline $\begin{array}{l}\text { Harm due to the } \\
\text { contact with plants, } \\
\text { animals, insects, or } \\
\text { reptiles }\end{array}$ & & & & & 1 & \\
\hline $\begin{array}{l}\text { Harm due to } \\
\text { wrongdoings of other } \\
\text { persons }\end{array}$ & & 1 & & & 2 & 1 \\
\hline
\end{tabular}

If we compare 2018 and 2019 we will see the increase in such severe accidents as falling from height - by 6 accidents or $80 \%$ and harm due to wrongdoings of other persons - by 2 accidents or $33.3 \%$. We will also see that the number of traumas due to the action of moving, rotating, flying parts, objects, or machinery, etc. decreased by 5 accidents or $50 \%$. Their severity also decreased (no fatal accidents).

The most traumatic sectors of the economy in the Kurgan region are the processing and agricultural industries. In 2019 there were 3 and 7 severe work accidents in these sectors, which accounted for $50 \%$ of their total number. We should also note that work accidents in the construction sector have the highest severity with 3 work accidents 2 of which were fatal.

In comparison to 2018, we did not find severe work accidents in such sectors as education, public administration, military safety, and welfare in 2019.

Also, between 2018 and 2019 there were no work accidents in the spheres of real estate and at the nonproduction facilities in such sectors as education and sectors providing other services.

\section{CONCLUSION}

The analysis of State Labour Inspectorate performance in the Kurgan region showed a slight decrease in main indicators of state supervision in the sphere of labour legislation due to a decline in the number of inspections by 206 cases between 2015 and 2019. The decline in inspections is explained by the lack of employees in the period between March and September 2019.

The data obtained in this research indicate that economic entities and their managers in the Kurgan region should cooperate with state authorities i.e. the State Labour Inspectorate and other local government bodies to decrease the number of work accidents in the region.

\section{References}

[1] V.N. Belkin, N.A. Belkina, O.A. Antonova, "Stimulation of Managers in Regional Enterprises", Econ. of reg., vol. 14, no. 1, pp. 123-136, 2018.

[2] V.N. Belkin, N.A. Belkina, O.A. Antonova, "Innovative Activity of Business Managers as a Condition for Modernization of Regional Labour Potential”, Econ. of reg., vol. 14, no. 4, pp. 1327-1340, 2018.

[3] V.N. Bobkov, V.G. Kvachev, N.V. Loktyukhina, M. Ricceri, "Criteria, Probability and Degree of Instability of Employment Taking into Account the Features of the Russian Labour Market”, Econ. of reg., vol. 13, no. 3, pp. 672-683, 2017.

[4] S.A. Karaush, O.O. Gerasimova, V.A. Senchenko, "The effectiveness of the work of the inspectors of Rostrud with the appeals of citizens about violations of labour legislation", Work safety, vol. 2, no. 79, pp. 26-27, 2019. (in Russian)

[5] R.V. Karapetyan, G.A. Menshikova, "III St. Petersburg International Labor Forum", Sociolog. studies, no. 6, pp. 148-150, 2019.

[6] S.A. Karaush, V.A. Senchenko, O.O. Gerasimova, "The effectiveness of state supervision over labour safety in Russia", Work safety at industr. enterprises, no. 6, pp. 44-49, 2019.

[7] N.A. Pilyaev, "IV all-Russian week of work safety", Occupational safety in industry, no. 5, pp. 75-77, 2018.

[8] E.A. Popova, D.S. Lyubimiy, "Work accidents", Work safety at industrial enterprises, no. 3, pp. 28-29, 2019.

[9] V. Pupkov, "Reducing the number of industrial injuries", Work safety at industrial enterprises, no. 2, pp. 58-61, 2019.

[10] I.A. Roznin, N.V. Roznina, M.V. Karpova, "The violation of labour safety at the Kurgan region enterprises", Issues of modern econ., no. 3, pp. 829-834, 2019.

[11] I.A. Roznin, N.V. Roznina, M.V. Karpova, "Industrial injuries at economic entities in the Kurgan region for 6 month of 2018", Issues of modern econ., no. 3, pp. 187-191, 2019.

[12] V.A. Senchenko, "Control over the state of working environment and occupational safety" Work safety at industr. enterprises, no. 9, pp. 52-60, 2019

[13] S.A. Syurin, A.A. Kovshov, "Labour conditions and risk of occupational pathology at the enterprises of the Arctic zone of the Russian Federation", Human ecol., no. 10, pp. 15-23, 2019.

[14] Yu.M. Filatov, Lee Khi Un, A.F. Pavlov, D.V. Gavrilov, V.V. Sobolev, A.V. Zelinskiy, "Improvement and Development of the Operational Management Systems for Occupational and Industrial Safety", Occupational safety in industry, no. 9, pp. 22-25, 2019.

[15] A.G. Khrupachev, A.A. Khadartsev, O.A. Sedova, L.V. Kashintseva, I.A. Kabanov, "Application of the Methodology of Labor Experience Safe Potential for Assessment of Economic Effectiveness of Occupational Safety Measures", Occupat. safety in industry, no. 9, pp. 89-95, 2019. 